\title{
Two Types of Magic in One Tradition? A Cognitive-Historiographical Case Study on the Interplay of Narratives and Rituals
}

DIRK JOHANNSEN

\section{INTRODUCTION}

Magic has a long tradition as a literary topos in the European history of religion. From antiquity onward, scholarly theories and poetic descriptions have suggested magic as a transhistorical and substantive phenomenon, while its alleged historical performances mostly turn out as attributions meant to marginalize or exclude rival parties. Until the modern institutionalization in occult orders, the self-declared magician had, with few exceptions, remained a fictional character, portrayed in varied ways depending on literary or scholarly genre (see Daxelmüller and Otto). In modern day literature, two contradictory types seem to stick out in particular. On the one hand, there is the classical "Faust-type" of character: people skilled in occult knowledge and with high ambitions, learned in the dark arts of performing rituals to evoke demons or craft instruments. The source of their power is a coalition with demonic, non-human entities or, as a heritage of modern occultism, the use of "cosmic" or "spiritual" energies that are channelled by the trained magician - like in Harry Potter's wand-based magic. On the other hand, there are the archetypal "Merlin-type" characters in present-day fantasy literature, who are magical beings themselves. Their 
magic is not restricted by spells and rituals, but derives or emanates from a source of power intrinsic to them. ${ }^{1}$ In scholarly debate, these two basic concepts of superempirical agency have long been identified and seen as mutually exclusive. Nicholas of Cusa, for example, stressed that it is a dangerous misunderstanding to regard magical effects as the result of the magician's peculiar nature. Responsible for the assumed effects produced "is not the fantastic [nature] of the magicians, who allege that by faith and through certain practices a man ascends to a nature of influential spirits who are akin to himself $-[\ldots]$. [S] uch (magicians) are bound to alliances, and to pacts of unity, with evil spirits" (Hopkins 253). ${ }^{2}$ In certain folk religious traditions, however, both concepts of superempirical agency - as an attribute of the practitioner himself and as external entities whose power is mediated by the practitioner - coexist.

This chapter provides a narratologically informed case study on a folk religious tradition in 19th-century southern Norway, in which the concept of trolldom seems to imply just this kind of contrasting notions. ${ }^{3}$ In Norway, the local oral traditions as well as customs and ritualistic practices have been collected and documented extensively since the 1830s. In the context of the nation-building programme following Danish rule, the skills of the traditional storytellers and the "peasant culture" were discovered as national heritage and led to the establishment of large folkloristic archives. ${ }^{4}$

1 The figure of the magician and the concepts of magic in modern literature have only partially been topics in literary studies. Stockhammer distinguishes between several types of magicians within the "supranaturalistic" and fantastic framework of modern literature. Here, a similar dichotomy can be discerned with the charismatic and magical individuals on the one side, and the hypnotists, alchemists and cabbalists on the other side (see Stockhammer).

2 Cf. Nicolaus Cusanus, De Docta Ignorantia, Liber III, c. XI [1440].

3 On the concept of folk religiosity (folkelig religiøsitet) as being characterized by a broader spectrum of beliefs and customs than recognized in official (Lutheran) doctrine see Skjelbred (68) and Eriksen.

4 This chapter focuses on sources from the inner Telemark province in southern Norway and claims validity for this region. Where I refer to sources from neighbouring provinces, the motifs were known in Telemark as well. The recordings were done by folklorists and clergy people, but even more by storytellers, peasants and local amateur historiographers. Keeping in mind the political dimen- 
Accompanied by a substantial ethnographic corpus, these collections allow a glimpse into 19th-century narrative cultures and their social context, in which trolldom is a dominant topic. It has long been noticed that, depending on the sources referred to, trolldom is described in a way that seems contradictory (see Lid and Grambo). In the legends, trolldom appears as a force intrinsic to certain cunning people. However, this legendary idealization of magical experts contrasts sharply with the actual practice of the same cunning people, as documented in ritual instructions and the ethnographic record. In most folkloristic studies on magic and popular customs, the legends, being fictions, were discounted as meaningful sources. My argument intends to show that despite the apparent dichotomy both rituals and fictional narratives are crucial to the tradition, as only their interplay creates distinct dynamics allowing the tradition to stay in place by renewing its potency and adapting to changing circumstances. In the legends, magic, indeed, comes as a fictional motif, but this motif develops social efficacy. In the following, I will approach the question on the interplay and the respective function of rituals and narratives by applying perspectives from narrative theory and the cognitive science of religion. Two cognitive ritual theories, the ritual competence theory by Thomas Lawson and Robert McCauley and the modes of religiosity theory advanced by Harvey Whitehouse, will be introduced and applied to the historical sources. While the former focuses on ritual syntax, allowing for a classification of ritual forms both in instruction manuals and in narrative descriptions of ritualistic acts, the latter is suited to model the dynamic connections of different types of rituals within a social setting. Although the results are confined to this specific historical setting, the methodological aim is to show how perspectives and models developed in these approaches can be integrated into historiography to provide both a coherent framework and specific instruments for detailed case studies in the history of religions.

sion of the enterprise, the collections - primarily the Norsk Folkeminnesamling - still provide an excellent corpus for comparative research in narrative cultures. Concerning the criticism of the sources and the question of authenticity see Johannsen (100-111). All translations are mine. 


\section{ReCipes ANd Stories}

The generic term for the semantic field of magic, sorcery, and witchcraft in the southern Norwegian tradition examined is trolldom, derived from Old Norse trolldomr. ${ }^{5}$ Although the term was commonly used to translate "magic" and "witchcraft" since the Middle Ages - leading to mostly overlapping conceptual histories -, the notion of trolldom still bears one significant peculiarity in respect to antique and Christian conceptions of magic. The agency is already captured in the term: trolldom is what trolls do. Before the national romanticist re-invention of folklore in the late 19th century, the word troll denoted not a singular species of legendary entities but was an attribute of uncanny beings and everything opposed to human society (see Hartmann). ${ }^{6}$ In the oral tradition of southern Norway, elves or the Hidden People (huldrefolk) are trollfolk, and so are Sami and Gypsies. Even animals, places or objects can be troll (Johannsen 183-187). A famous example are the Black Books, handwritten collections of recipes and formulas including herbal cures and poisons, charms, spells, and rites for calling forth Jesus, saints, Satan or the elves - practices a trollmann (sorcerer) or a trollkvinne (witch) would be suspected of. More than 150 of these handwritten manuscripts were found in Norway, and although some date back as far as the 15th century, most of them are of relatively recent origin (see Bang; Garstein; Amundsen, Svarteboken). They derive from late 18th- and 19th-century peasant culture, even though they bear titles meant to convince the readers of their extraordinary age and value: "Cyprianus Arts. A book written in the Academy of Wittenberg Anno 1345 and later found in the palace of Copenhagen Anno 1665 in a chest of marble, written on parchment." In the oral tradition these manuals were a frequent topic, but had adopted an even darker, "trollish" character which makes the "ex-

5 On the concept in Old Norse literature see Raudvere. The loan word "magi" is hardly ever used in the sources examined.

6 Troll is a neuter noun that also used to function as an adjective.

7 Norsk Folkeminnesamling: NFS Moltke Moe 106 I. Most of the manuscripts have been digitalized at the IKOS, University of Oslo (http://www.edd.uio.no/ ikos/svarteboker/svarteboker.html). The "Black Academy of Wittenberg," where the devil himself teaches, is the motif of a migratory legend (ML 3000) obviously dating back to the Counter Reformation (see Christiansen). 
tant Black Books seem naive and prosaic" (Espeland 13-14). ${ }^{8}$ In the legends, the books are described as being dangerous not because of their blasphemous content but as mere objects, as they almost seem to bristle with power. They enslave their owners, they cannot be destroyed or got rid of, and opening them calls forth all forms of trollskap and leads to insanity unless one is a trollmann already. In that case, however, the content of these books is completely irrelevant, because these legendary figures are in no need of knowledge. Their power is intrinsic to them, as they are troll themselves.

In 19th-century Norway, there was a large scene of cunning people. The most famous served as general healers using herbs and homemade drugs something that was of vast importance in the rural areas where access to conventional medical treatment was rare and mostly too expensive. The borders between these healers and practitioners of more dubious arts were fluid (see Stokker). There were specialists who would take care only of specific ailments or injuries, like curing a sprain by placing the patient's limb on a stump and then pretending to chop wood while reciting a formula to reduce the pain ("knocking the pain off"). Rituals for worldly purposes, like predicting one's future spouse, inducing love, or increasing luck in financial matters were included in the repertoire of some of the healers. In the case of a forest fire, an ildstemmer (fire-stopper) was called to perform the odd task of running around the trouble spot reciting charms, so the fire would not be able to cross his path (Hodne, Trolldom i Norge 165-195). Most of the rituals described in the historical Black Books are relatively detailed instructions for performing this kind of ritualistic act accurately. Two of the most common themes were staunching blood and catching thieves. Similar to the fire-stoppers, blood-stoppers were mostly specialists, even though the ritual requirements were rather simple. For example, for staunching blood, a "trollbøn" (magic prayer) would be declaimed while applying white moss: "Staunch blood and arrest blood for N.N. [the patient], like the stream stood still when Jesus and his 10 disciples went over the water." ${ }^{9}$ More elaborate were the rituals for finding thieves by "showing

8 Many of the migratory legends of the types ML 3000 - 3025 centre on the Black Book.

9 NFS Moltke Moe 106 I [18th century]. 
them in the water" (vise $i$ vannet or igjenvise), that is conjuring an image of the thief on the water's surface:

Make yourself $3 \mathrm{X}$ [crosses] out of rowan tree and go to a small river, where it runs from east to west, on a Friday morning before the sun dawns. Throw the crosses into the water where they cannot float away and read the following words over the crosses: I call you and I beg you, highest Lord Lusefærd [Lucifer] and the Lord Geamataan [?], by your Power and Authority to bring me back what N. [the name of the thief] has stolen from N.N. [the client's name], or that you show me the thief's name and picture here in the water. And that he might become so crazy in his heart and his God and his mind that the earth shakes under his feet in 15,000 devils' name. ${ }^{10}$

The formulaic character is typical of rituals performed in the local community - both by cunning people and laymen. The charms had to be phrased and carried out precisely according to the tradition, calling upon saints, demons or the Hidden People, who in local custom stood side by side with entities from Christian tradition.

Beside the Black Books and the ethnographic record, the oral tradition collected in the 19th century provides additional insight into the conventional notions of trolldom and its practitioners. The legendary trolldom serves mostly the same purposes as the rituals described, but the ritual acts are hardly ever mentioned. In the legends, a trollmann will be called to staunch bleeding, but he will use no formulated charm and certainly not refer to Jesus. A common motif is that he welcomes a messenger with the words: "You can go home again, for the wound is closed already" (Hodne, Trolldom i Norge 184). When showing a thief in the water, the legendary trollmann will simply point to a bucket for the image to appear, an act causing horror among the spectators. The magical effects are always immediate. In many cases of theft, the trollmann even seems to do nothing at all, as in the following legend of one infamous "wise-priest":

Once, it is told, the parish priest called Finkenhagen lost a silver spoon when performing the church service in Tuddal. The people looked for it but could not find it anywhere, so the priest had to continue his journey without the spoon. As he had

10 NB Ms. $8^{\circ}$ 640:a, op. 56 (Cypirianus Frikonst udgivet udi aaredt 1719 [ca. 1780]). 
come midway to the hill with the pasture called 'Sveinungshovden' he descended from his horse to rest and said to his companion: "We should wait a moment, he will make him sweat to come after us [sic]." After a short while, a man became visible down in the valley. He came rushing after them with a spoon in one hand and a handkerchief in the other hand, wiping off the dripping sweat. "Here I come with the spoon which you forgot," he said to the priest as he approached. "Yes, that may be so," said the priest and laughed. It turned out that the man had stolen the silver spoon from the priest's room and that he - after the priest left - was unable to find any rest or peace of mind. He had to take the spoon and run after the priest. ${ }^{11}$

Instead of describing rituals, the legends focus on portraying the trollmenn as powerful and intimidating figures, whose mere presence leads to strong emotional and bodily reactions, allowing them to control other people's behaviour:

[At a dance, the trollmann] Eilev hopped on the bed, and before anyone realized what was going on, the girl hauled to the bed, undressed and laid down beside him, so everyone in the dancing parlour would see it. It took quite a while before she recovered, being embarrassed and getting mocked and laughed at (Flatin 97).

In the legends, magic is not something to be learned. A trollmann is somebody who had an encounter with something troll; he might have been abducted by elves, been in contact with demons, ethnic minorities, another trollmann, or a Black Book (see Mathisen, "North Norwegian Folk Legends" and "Den farlige kunnskapen"). By being with trolls, people become troll themselves. To understand this concept of magical agency, we have to take a closer look at what precisely the word troll refers to within the legends.

\section{Troll as a Semantic Vacancy}

Things troll are the substrate of mythical legends from 19th-century southern Norway. Telling these legends was considered an art, with proficient

11 NFS Klipp VII, p. 64 (Fremskridt Nr. 238, 24/9/1903), Telemark. Emphasis in the original. 
storytellers being the keepers of a region's history. ${ }^{12}$ In the legends, they present a world inhabited by ghosts and nature spirits, by witches and sorcerers. The stories were meant as entertainment and were subject to controversy and debate. On the one hand, the existence of these beings was doubted by some members of the local community, sometimes understood as allegorical, and their relation to the Christian doctrine was even a theological dispute (Amundsen, "Mellom inderlighet og fornuft" 268-297). On the other hand, stories about Hidden People granting a rich harvest or occupying an alp during the winter months legitimized land claims of those parties within the local community who were known as having a close relationship with these entities (see Solheim). The stories explained genealogies, unusual events and created mysteries to ponder; the range of interpretation, as it is documented in the historical collections, was enormous. In part, this is due to some stylistic features, which can be identified as the conventional patterns of this narrative tradition. Far from being made up spontaneously, the legends told can be shown to follow a strict set of motifs and stylistic rules, which aimed at provoking curiosity and involvement. Regarding the question of what precisely is indicated by the term troll, these patterns become visible, as they apply to the representation of superempirical respectively counterintuitive agents in their entirety. ${ }^{13}$

Legends are told from the perspective of the local community. Even if the motifs are those of migratory legends known all over Europe, in the local variants the protagonists are people known by name and family, and the places of the events are precisely specified. The narrative perspective, too, seems bound to the community, and is actively used to construct the "otherness" which defines certain people and beings as troll. The legends' conventional perspective is a third-person omniscient point of view with full

12 On the storytellers' social position see Bø et. al. (11-60).

13 Instead of "supernatural entities, " "culturally postulated superhuman agents," or "intermediate beings" I refer to religious and fantastic entities as counterintuitive, as this term by Pascal Boyer is the only one referring solely to structural features instead of cultural presuppositions or an artificial dichotomy between theological and folkloristic concepts (see Boyer). The underlying theory defines counterintuitivity as "a transgression of a number of ontological features rooted in human cognition" (Severi 816). These features, of course, have to be defined on an empirical base. 
access to the characters' emotions and thoughts. The heterodiegetic narrator, however, refrains from any statement concerning the inner life of the superempirical characters in the legends. Although even the spirits of local folklore are highly anthropomorphic and their outer appearance is often described as indistinguishable from ordinary people, their mind remains a black box. ${ }^{14}$ Their knowledge and their intentions are never revealed. In episodes describing encounters, this stylistic distance between the narrator and the superempirical beings is maintained by a shift from the conventional zero-focalized point of view to an internal focalization of a human protagonist on the diegetic level, who faces these entities confused and marvelled. In many cases, this sudden shift to a more limited perspective is the only clue to what kind of being the protagonists are dealing with. For example, in one legend two young huntsmen spend the night in a remote cottage in the highlands:

After their meal they cleaned up and rested on the beds they made from fir branches, when suddenly a woman entered, followed by two young girls. The huntsmen became afraid; they thought it strange that somebody would be out here that late. But since they noticed nothing dangerous, they regained some courage. After all, they trusted their rifles. They thought it might be the extraordinarily pretty girls who were said to tend cattle out here. Perhaps they came from the village. Perhaps they lost track of time. Essentially, they did not know what to think (Loupedalen 257f).

Filtered through the protagonists' emotional arousal, questions and doubts, the story suggests a mystery, even if nothing counterintuitive happens. As the visitors are not introduced, in the context of the legends it is already obvious that the two huntsmen have an encounter with something troll, in this case the Hidden People.

The technical character of this shift in focalization becomes obvious in the more elaborate legends. The single most dominant motif in the narrative tradition is the story of people who, either for a short time or for the rest of their lives, were taken into the mountain (bergtatt). Underground and inside

14 In some legends, the female forest spirit huldra has a cow's tail, but even this well known trait is not mandatory. This and similar traits are mentioned only where necessary for the plot structure - with the protagonist discovering it in the last moment. 
the hills, the Hidden People dwelled, as did their ancestors, the vattir and elves of Old Norse literature. According to the motif, the protagonist suddenly stumbles into their home or is allured by their extraordinary beauty and, despite his or her fears and attempts to resist, follows them to their abode. But as soon as the protagonist enters, he or she is lost to society, and therefore to the narrator as well: "Somebody 'taken in' will never again be a proper human being" (Holbek and Piø, 112; see also Feilberg). A typical trait of this legendary motif is the coda, in which the protagonist after some time returns home alienated, mostly unable to utter a meaningful word and yearning to go back to "the mountain," or sometimes empowered as a trollmann, with abilities far beyond human reach. Alternatively, he or she stays with the Hidden People and becomes one of them. Remarkably, it never becomes quite clear if this is judged as a good or a bad thing to happen to the people concerned. While the bereaved take a lot of trouble to get them back, for example in fruitless attempts to carry church bells up to the mountain, the storyline provides the abductees with a final word of goodbye, often emphasizing how much better off they are: "to me, it is like Christmas every day" (Johannsen 143-151).

After the initial encounter, the legend's point of view shifts back to the normal zero focalization focusing on the people left behind, while the events in the Hidden People's realm remain untold. The former focalizer is now subject to the same stylistic distance used to characterize all superempirical beings. The moral is ambivalent and so is the character of the trollfolk: by artificially restricting the knowledge to the communal consent about these entities, they are constructed as a mystery. A semantic vacancy or blank is installed as the core of these types of legends. ${ }^{15}$ The trolls' nature and relation to human society are left for the audience to debate, and by doing so, a community's norms, beliefs, and boundaries have to be negotiated. The counterintuitive effects produced by trollfolk, with Hidden People vanishing right before one's eyes or the empowered returnees per-

15 What is described by Wolfgang Iser as a general operational principle of fictional literature, the gaps or blanks "organizing the readers participation" (203) by "a process set in motion and regulated not by a given code but by a mutually restrictive and magnifying interaction between the explicit and the implicit, between revelation and concealment" (168f.), can for this genre be understood as a narrative technique purposefully applied at the core of the tradition. 
forming incredible acts of trolldom, come as a result of this ambiguity. With the rule of stylistic distance, their knowledge and abilities are defined as being beyond reach. Every question about "how it is done" leads back to a blank, which is the narrative core of the concept of troll, and thus can only be answered by referring to other stories.

\section{Trolldom and the Form of Ritual Acts}

Within the folk religious tradition, trolldom seems to come in two types. On the one hand, manuals describe elaborate rituals involving formulaic speech, a diversity of items and detailed instructions on how to conduct each step of the ritual. The legends, on the other hand, describe trolldom as an intrinsic property of people and beings troll with effects achieved immediately. Even if it is assumed that legends focus on the extraordinary outcomes rather than preparatory measures, the absence of rituals is still striking. It seems as if the legendary trolldom hardly knows of any formulaic rituals and thus as if two antithetic concepts of magical agency coexisted within the local tradition. This, however, is not the case. The effective agency assumed in the stories about trolldom is the same as in the ritual performances, and indeed they constitute a coherent system. The apparent discrepancy is the result of the different ritual forms represented, which both have their respective function in relation to one other.

The gap between the narrative portrayal and the actual performance of acts of trolldom can be bridged by applying a cognitive perspective, focusing on the ascription of superempirical agency. The structure of the magical acts can be rendered according to the ritual form hypothesis put forward in the theory of religious ritual competence by Thomas Lawson and Robert McCauley. Modelled after Noam Chomsky's language competence theory, the theory posits a cognitive processing device called the Action Representation System, which checks the well-formedness of notions of actions and generates predictable intuitions about their probable efficacy. The postulated three-slot pattern is one of subject, predicate and object: an agent does something to (or uses something on) a patient [Agent $\rightarrow$ Instrument (Action) $\rightarrow$ Patient]. The hypothesis states that religious ritual acts are really like ordinary acts, but include the efficacy of a counterintuitive agent in one of the three possible slots, thus allowing for a non-natural consequence. 
Depending on the slot connected to this special agency, thus the prognosis, rituals will be perceived strikingly different.

Special Agent Rituals are those in which the person performing the act has a ritually mediated connection to a counterintuitive agent. Examples are the sacraments of the Catholic Church, which normally have to be given by an ordained member of the clergy. Ordained priests stand in the apostolic succession, which provides a direct and - in theory - unbroken link to the enabling acts performed by God, allowing them to act on His behalf when giving the sacrament. Rituals, in which the special agency is exercized via a person, are acts which, indirectly, are conducted by the counterintuitive agent and are therefore not reversible by human means. Furthermore, for the effect to stay in place, no repetition is needed. The effect of a ritual like matrimony or baptism is lasting. ${ }^{16}$ Lawson and McCauley condense the intuitive consequences of this form of rituals in the so-called Principle of Superhuman Agency: Special Agent Rituals will be relatively rare and infrequently performed, emotionally arousing happenings, coded in episodic memory.

In contrast to Special Agent Rituals, Special Instrument Rituals as well as Special Patient Rituals have a rather different ritual profile, as they both tend to be repeated frequently. In these forms of rituals, the counterintuitive agent is referred to in the action/instrument slot (like when using magical gestures, charms, spells, talismans, relics etc.) or in the patient slot, when it becomes the receiving part of a ritual (say sacrifices to a god). As the actors are humans who are not acting on behalf of a supporting superempirical agency, the attributed effect is usually less intense and lasting, requiring constant updates. The Principle of Superhuman Agency predicts that these two forms of rituals will, due to their frequency, come with less emotional arousal on average and be coded in semantic memory. Where several slots provide ritually mediated connections to counterintuitive agents, like baptism involving a priest as the agent and holy water consecrated by a priest as the instrument, the initial appearance is the one more direct, i.e., the entry with the fewest enabling rituals. This additional rule, the Principle of

16 The theory does not state that exceptions from this inner logic, like emergency baptism, are a theological problem, but that these exceptions will eventually lead to controversy, as they contradict intuitive (and often "theologically incorrect") assumptions derived from the ritual form (Slone 57). 
Superhuman Immediacy, implies that the attributed efficacy of rituals tends to fade if no new connections to the counterintuitive agents are established (Lawson and McCauley 26ff.)

The ritual form hypothesis allows rituals to be classified according to the element of the (either performed or described) act perceived as crucial for their efficacy and thus rated as not exchangeable. It is the form rather than the type in which ritualistic acts from the Black Books differ from those represented in the legends. The acts of trolldom described in the manuals and the ethnographic record are in virtually all cases either Special Instrument Rituals or Special Patient Rituals. The ritual form does not require the performer to be a special agent with counterintuitive attributes or skills. Any person of certain learning and with access to the required objects will in principle be able to execute the magical procedures. Required are either items with a connection to counterintuitive agents or a direct addressing of these agents. Neither in the manuals nor in the ethnographic record is there a sharp distinction between entities from the Christian traditions and those from a more folk religious background, as a connection to both of them is able to provide the sufficient "magical essence"; while God's power is utilized by crucifixes and charms, hosts or splinters from church altars, soil from graveyards may either refer to God, as it is consecrated, or to the (un-)dead. In the 19th century, many families owned pieces of silver tableware like spoons or jugs which were considered as elfin silver, former property of the Hidden People and thus still connected to their special agency. These items were said to unfold healing powers and used to administer medicine.

In the legends, trolldom is performed by special agents, and thus the formulas and items used are exchangeable and even dispensable. It is the practitioner who is connected to the counterintuitive entities. The folk religious spectrum remains in place, as this connection can be due to an encounter with the Hidden People or due to having visited the black academy of Wittenberg. Trollmenn, witches, and the wise priest (visepraest), "who can do more than just eat," stand side by side in the legends, and while their social status might differ, the extraordinary effects produced largely overlap. So although the narrative representations and the actual ritual performances seem to imply different notions of magic, the magical agency is still the same; in both cases, it leads back to the narrative substrate, the counterintuitive agents of the legends and the biblical stories, only that the 
rituals written down in the Black Books refer to them in the performance slots, while the legendary troll people incorporate them.

Having identified this connection, it becomes possible to take a closer look at the respective function of legends and rituals within the folk religious frame of thought and the general dynamics of the tradition. Both legendary motifs and conventional rituals are rather static in nature. They are documented as being relatively consistent over decades. And over the decades, they began to be questioned. "These words were powerful once" is a sentence often heard by ethnographers when asking about charms and spells. Consistent with Lawson's and McCauley's prediction, the Principle of Superhuman Immediacy, with every new generation, the superempirical agency referred to in the ritualistic acts seems to grow further apart. The legends of counterintuitive agents lose relevance and emotional impact where the connections to everyday life are not frequently renewed. However, the prediction that magical rituals and the oral tradition therefore will become extinct in the coming years, made already in the 18th century and repeated in every following generation, has proven incorrect. While the decline of belief in the "old traditions" is a frequent topic, later scholars observed that beliefs and practices that are ridiculed at one time can come to full bloom again in the following generation. External factors aside, one key to this phenomenon lies in the interplay of narratives and rituals. A case example will serve to illustrate the evolving dynamics, when both forms of magic enter into a synthesis.

\section{The Case of Spå-Eilev}

One of southern Norway's most famous magical experts in the second half of the 19th century was Eilev Olsen Hagen (1814-1891), known by the name of Spå-Eilev (Scry-Eilev). Born as the son of a day labourer in Hjuksebø, Sauherad, in the province of Telemark, he rapidly ascended the social ladder by becoming widely known as a professional soothsayer - and a legendary trollmann. He became the charismatic protagonist of hundreds of local legends. Eilev Olsen's peculiar career took off in 1838, when he 
became involved in a law suit. ${ }^{17}$ The case started out as a bagatelle, after a local peasant was accused of having stolen barley from his neighbour's barn. Since the accused had a bad reputation, the outcome seemed clear - at least until the accused's daughter broke a barrier of silence not even the accused had dared to touch. She revealed that her father was only blamed for one reason, which was that the key witness for the prosecution, Eilev Olsen, had "shown him in the water." The 24-year-old day labourer had used a magical technique to spot the thief. The trial now unexpectedly became Norway's last witch trial (trolldomsprosess), with Eilev Olsen being accused and dozens of witnesses summoned to court, almost all of them being familiar with Eilev's activities. It was put on record that he was a blasphemer who threatened to curse his enemies and who demanded to be worshipped, and he frequently acted as a soothsayer. Eilev Olsen tried to defend himself by stating that he "might have told fortunes" now and then using playing cards, but "if he had done so" then just for entertainment purposes. He had certainly not shown anyone "in the water." The voices of the witnesses could not be ignored, and on April 22, 1839 the court sentenced Eilev Olsen to three years of hard labour and subsequent exile. The verdict was based on the old witchcraft laws from the Norske Lov, put in place in 1687 and almost forgotten in the early 19th century. The judge himself, however, forgot about a minor detail: the witchcraft laws were set up under Danish rule, but as Norway had been under Swedish crown since 1814, substantial revisions were in progress. The ruling was appealed and on $\mathrm{Au}-$ gust 19, 1839, Eilev Olsen was acquitted of all charges, although the High Court (Hфyesterett) did not fail to comment that his soothsaying acts were reprehensible, even if no longer chargeable. The trolldom act was officially repealed in 1842 .

Concerning the concepts of magical agency, the most revealing passage in the sixty pages of court documents preserved is the local judge's question whether anyone had ever seen Eilev perform an act of trolldom. One

17 The following three records of this case are preserved in the Riksarkiv in Oslo: Høyesterett L. Nr 1-17, 1. sesjon 1840. Pk. nr. 3., Sak Nr. 52. / Høyesterettsdommer for 1840. Justisdepartmentets forskjellige protokoller nr. 58. Sak. nr. 52 / Høyesteretts voteringsprotokoll 1. sesjon 1840, S. 21/22 sak nr. 52.18. Februar 1840. No page numbers are given; all quotes following are from these manuscripts. On the process see Hodne, "Trolldomssaken mot Spå-Eilev." 
person stepped forth and declared he had seen Eilev once "lie motionless on a bench the whole day and when being asked about that, he said he was confused." So when asked for the indicated ritual act, the witnesses only reported an incident where he had done virtually nothing - which obviously seemed suspicious. Otherwise, only two clues regarding the nature of his practices were given. In a side note of the High Court documents it is mentioned that when telling the fortunes he used a printed manual, which might be a reference to one of the popular prints of Black Books from Copenhagen. ${ }^{18}$ Furthermore, it was reported that Eilev first worked as a soothsayer after a journey undertaken half a year earlier. In the years to come, the story of this journey became a legend. Eilev himself is said to have told how he met a Sami girl in Northern Norway and stayed with her for some time. It is a common variant of the "taken into the mountain"-motif: in local folklore the Sami were considered trollfolk, so he had become a trollmann by being with a troll. ${ }^{19}$

As the trial had made him famous, in the following fifty years he became a highly frequented and at the same time feared soothsayer and sorcerer. In a time of economic crisis, he moved up from being a day labourer to being a landowner with his own tenants. In dozens of legends, so many "one could easily write a substantial book just about him," he was portrayed telling fortunes, controlling people, and causing harm over vast distances (Flatin 97). The court proceedings - in which the local community had testified against Eilev - were not forgotten, but reinterpreted. Now it was told that he was the victim of a conspiracy, but due to his skills and wit easily got off the hook, leaving the judge stultified. The most common motif was still him finding thieves by "showing them in the water." This ritual practice is depicted as a sort of gimmick, as Spå-Eilev is almost omniscient anyway:

18 Popular versions of magical manuals were printed in Copenhagen since the beginning of the 19th century (Espeland 14).

19 The most extensive published collections of legends on Spå-Eilev can be found in Qvisling, Gunnhejm and Flatin. A large collection of unpublished legends can be found in the Rikard Berge Håndskriftsamling (Telemark Fylkesmuseum, Skien) and the Norsk Folkeminnesamling. 
In Slemdal, something was stolen. A girl named Ingeborg from Sauherad was employed at the neighbour's farm. The man who was stolen from went to her and asked her, since she knew Spå-Eilev, if she could persuade him to identify the thief. Indeed, Ingeborg went to Hjuksebø, where Eilev lived. He was standing outside the barn threshing. But as she went down there, she became so afraid she trembled all the way and her heart pounded as if it would burst. As she came to him, Eilev said: "You came because of a theft, and it seems strange that Olav, who is the son in Tingulvstad, does not understand who the thief is. He should realize who steals from him." Then Eilev began to tell her what the thief's home looked like, what the thief looked like and so on, and asked: "Do you think that, by this, you can find out who the thief is?" (He said no name). Ingeborg answered: "I guess I know who it is." "If you are not sure I can show him to you." "No! Anything but that!" - Ingeborg burst out. But Spå-Eilev called his wife to bring him a bowl of water, which she did. "Do you know the man sitting down there in the bowl?" Eilev asked. Ingeborg stared into the water and saw a man she knew, as clear as if she were looking at him face to face. "If you want I can mark him for you; I can put his eye out or something like that." Ingeborg called out: "For God's sake, don't do that!" "Well, sure, I can just leave it be," Eilev said (Gunnhejm 107f.).

As a legendary figure, Spå-Eilev is represented according to the stylistic conventions of the narrative tradition. While the storyline follows the local girl, his character is built up as enigmatic and powerful by a description of the girl's strong bodily reaction to his presence. Although she is the one making a request, he remains in control, answering before the question is uttered. By ignoring her wishes and showing the thief in the water, he demonstrates both his superempirical abilities and his social dominance. Spå-Eilev's intentions and the range of his power remain ambiguous; his thoughts and emotions are generally hidden from the narrator's point of view, while the clients and other members of the local community serve as focalizers. The legends match the prediction of Lawson's and McCauley's Principle of Superhuman Agency. Spå-Eilev's acts of trolldom are always depicted as singular, outstanding episodes. The legends simulate emotional arousal by focussing on the emotional impact of the sorcerer as a special agent. When he makes a thief appear on the water's surface, the clients tremble and feel horror; if he reads their minds, they are stunned; just encountering him comes with descriptions of fear, fascination, and often stupor. What Eilev does, in contrast, seems random. Where legends were col- 
lected in several variants, the course of action is interchangeable and the superempirical effects produced always seem the immediate result of his intrinsic powers, such as when he answers questions not even posed yet.

By the end of the 19th century, some of his late clients described to the lay folklorist Christian Gunnhejm what happened during the consultation. Years after Eilev Olsen's death those clients showed themselves deeply impressed by his personality and skills, even marking the consultation as a watershed moment in their lives. The accounts recorded by Gunnhejm can be classified as memorates: autodiegetic narratives of personal experience that mirror the legends both in style and in content (see Honko). The situations described are similar, with Eilev seemingly anticipating the clients' visit and most of their questions. His fortune telling, however, gains a distinct ritualistic component, as the clients report how he read coffee grounds when giving advice on everyday problems. And of course Spå-Eilev's magical leitmotif is mentioned, even though never performed. Asked by a client about his future spouse the client remembers Eilev offering to "show" her: "If you want I can show her to you in a cup of water; but since she is so far away, it would not do her any good" (Gunnhejm 105). As often as the offer is given, it is turned down due to the carefully announced side effects. Against the background of the legends, which conventionalized him as a charismatic authority, the consultation was an experience worth reporting anyway. Within the narrative frame he had developed a social potency. Gunnhejm suggests that Eilev's extraordinary success as a soothsayer was the outcome of his legendary reputation rather than being its cause: "Many did not dare otherwise but to return the stolen goods as soon as they heard Spå-Eilev had gotten involved" (88). In this way, his practice and the stories about his practice together might have constituted a self-affirming system, where the formulaic rituals, even if performed, indeed played an almost negligible role.

\section{RejuVEnating the Tradition}

As the case of Spå-Eilev illustrates, both forms of trolldom - as legendary acts of special agents and as special instrument or special patient rituals are deeply intertwined within the local tradition. Although both the legendary motifs and the conventional rituals are static in nature, in their interplay 
they develop dynamic qualities and social efficacy. The mechanism of this process, in the centre of which stands the ascription of a special agency to a member of the community, can be explained by a cognitive model elaborated by Jesper Sørensen, based on Harvey Whitehouse's modes of religiosity theory (see Sørensen).

The modes theory addresses the interaction of different forms of rituals with systems of belief and social structures (see Whitehouse). Similar to Lawson and McCauley's case for the rituals, Whitehouse argues for two cognitive attractor positions within religious systems, deduced from two modes of transmission of religious content, one connected to episodic, one to semantic memory. The imagistic mode centres on emotionally arousing, infrequently performed rituals. The level of arousal leads to an episodic encoding of the event. The performers will remember this specific performance in great detail, leading to increased social cohesion and "spontaneous exegetic reflexions" about the ritual experience. As the episodic memories will be retrieved in narrative form, choices of narrative style, genre and patterns will influence these reflexions. If the rituals become routine, the theory predicts a progressive shift to the doctrinal mode attractor position, as the performance will be coded in semantic memory and certain interpretations will be established as authoritative. This leads to the strong bonds between participants sharing the experience being reduced, and resources set free for the elaboration of complex systems of belief imparted by organized specialists. The doctrinal mode is no stable outcome either, as the more complex and less experiential cluster of beliefs, hierarchies and rituals will, according to Whitehouse, lead to a "tedium effect." With less personal involvement and references to an individual's life, a reversal of the process is initiated. As the two modes are meant as attractor positions, a religious tradition will oscillate between these poles. ${ }^{20}$

As Jesper Sørensen has pointed out, the modes theory may help to identify "both cognitive and social pressures" on the tradition, which lead to the ascription of charismatic authority (181). The special instrument rituals as documented in the Black Books and the ethnographic record are part of a

20 It is hard to estimate on which scale of historical processes the dynamics postulated in the modes theory actually occur, as it was developed in an anthropological context. For the purpose of this study, however, it may serve as a heuristic model. For applications on different scales see Whitehouse and Martin. 
dogmatic system, in which trained magical experts, most of them coming from family traditions, were concerned with clear-cut domains and dealt with a sophisticated apparatus of formulas and recipes referring to folk religious entities. Failing rituals, an increasing amount of instructions, interpretations and forms of specialism will tend to decrease the efficacy accorded to these rituals (168). Weakness of the dogmatic system combined with the cognitive propensity for essentialist thinking will, according to Sørensen, set the stage for charismatic conceptions which allow for the tradition to refocus. As the accused in a highly unusual lawsuit, the soothsayer Eilev Olsen became the subject of stories, which adopted the stylistic patterns from the oral tradition. As a legendary trollmann empowered by a transforming encounter, Spå-Eilev does not only stand in a tradition of cunning people, but embodies this tradition. In the stories, he performs the traditional special instrument acts as a special agent, renewing their connection to the active principle and reducing them to their bare minimum. Not being bound by doctrines and recipes, his narratively constructed authority stabilized and rejuvenated the system.

\section{CONCLUSION}

The legends attach emotional arousal and memorable episodes to traditional ritual acts. Their narrative core was identified in the concept of troll as having no positive attributes, but being a semantic vacancy established by a set of conventional stylistic patterns mandatory to this specific oral tradition. With contemporaries narratively constructed as trollpeople, they provide a general reference to the superempirical agencies of the folk religious frame of thought without already subscribing to a particular theory of magic. As simulated special agent acts the stories only add a necessary component for the ritualistic tradition to stay in place. They recharge the rituals with meaning and efficacy. The narrative tradition, thus, can be identified as a crucial element of ritual performances - even if the legends hardly ever mention the ritual acts in detail. Far from being mere illustrations, the episodes told legitimize and rejuvenate the folk religious tradition, allowing for it to adapt to changing circumstances, doctrines and the life worlds of new generations. 
The aim of this chapter was to show how a historiographical approach benefits from a mixed approach of narrative and ritual theories. Seen individually, the rituals and narratives of the tradition examined are relatively static, and a focus on either one of them will suggest beliefs and performances to be equally static. The historical studies derived from this perspective will therefore always identify external factors as the crucial component for historical developments. A theoretically informed approach can do more than just provide interpretations of stories and customs at a given time. By revealing basic structures of the form of rituals within narratives and the narrative requirements of ritual forms, the researcher's attention is drawn from the content towards their structural intersection. In this way, the inner dynamics of components otherwise perceived as separate come into view.

\section{REFERENCES}

Amundsen, Arne B. Svarteboken fra Borge. Sarpsborg: Borgarsyssel Museum, 1987.

—. "Mellom inderlighet og fornuft." Norges religionshistorie. Eds. Arne B. Amundsen et al. Oslo: Universitetsforlaget, 2005. 243-294.

Bang, Anton Christian. Norske Hexeformularer og Magiske Opskrifter. Kristiania: Jacob Dybwad, 1901.

Boyer, Pascal. The Naturalness of Religious Ideas. A Cognitive Theory of Religion. Berkeley, CA: U of California P, 1994.

B $\varnothing$, Olav, Ronald Grambo, Bjarne Hodne, and Ørnulf Hodne. Norske Segner. Oslo: Det Norske Samlaget, 1995.

Christiansen, Reidar Thoralf. The Migratory Legends. A Proposed List of Types with a Systematic Catalogue of the Norwegian Variants. Helsinki: Suomalainen Tiedeakatemia, 1958.

Daxelmüller, Christoph. Zauberpraktiken. Eine Ideengeschichte der Magie. Düsseldorf: Albatros/Patmos, 2005.

Eriksen, Anne. "Folkelig religiøsitet: fors $\varnothing \mathrm{k}$ til en avklaring." Tradisjon 23 (1993): 57-66.

Espeland, Velle. "Svartebøker frå Telemark." Telemark Historie - Tidsskrift for Telemark Historielag 24 (2003): 13-26.

Feilberg, Henning F. Bjargtagen. Studie over en gruppe trak fra nordisk alfetro. København: Det Schønbergske Forlag, 1910. 
Flatin, Kjetil A. Tussar og trolldom. Oslo: Norsk Folkeminnelag, 1930.

Garstein, Oskar. Vinjeboka - den eldste svartebok fra norsk middelalder. Oslo: Solum, 1993.

Grambo, Ronald. Norske trollformler og magiske ritualer. Oslo: Universitetsforlaget, 1979.

Gunnhejm, Christoffer. Gamalt fraa Telemork. Segner og sogur. Skien: Erik St. Nilssens, 1915.

Hartmann, Elisabeth. Die Trollvorstellungen in den Sagen und Märchen der skandinavischen Völker. Stuttgart: Kohlhammer, 1936.

Hodne, Ørnulf (1981). "Trolldomssaken mot Spå-Eilev. En undersøkelse av holdninger." Norveg. Folkelivsgransking 24 (1981): 7-40.

-. Trolldom i Norge. Hekser og trollmenn i folketro og lokaltradisjon. Oslo: Cappelen, 2008.

Holbek, Bengt, and Iørn Piø. Fabeldyr og Sagnfolk. København: Politikens Forlag, 1967.

Honko, Lauri (1964). "Memorates and the Study of Folk Beliefs." Journal of the Folklore Institute 1 (1964): 5-19.

Hopkins, Jasper, ed. Nicholas of Cusa on Learned Ignorance: A Translation and an Appraisal of De Docta Ignorantia. Minneapolis: Arthur J Banning Press, 1985.

Iser, Wolfgang. The Act of Reading. A Theory of Aesthetic Response. London: Routledge \& Kegan Paul, 1978.

Johannsen, Dirk. Das Numinose als kulturwissenschaftliche Kategorie. Norwegische Sagenwelt in religionswissenschaftlicher Deutung. Stuttgart: Kohlhammer, 2008.

Lawson, Thomas E., and Robert N. McCauley. Bringing Ritual to Mind. Psychological Foundations of Ritual Forms. Cambridge: Cambridge UP, 2002.

Lid, Nils. Trolldom. Nordiske studiar. Oslo: Cammermeyer, 1950.

Loupedalen, Knut. Eventyr og Segnir fraa Telemarki. Oslo: Cammermeyer, 1923.

Mathisen, Stein R. "North Norwegian Folk Legends about the Secret Knowledge of the Magic Experts." Arv - Nordic Yearbook of Folklore 48 (1993): 19-27.

—. "Den farlige kunnskapen. Makter, moral og viten i sagn om svarteboka." Mellom sagn og virkelighet $i$ nordnorsk tradisjon. Eds. Marit 
Anne Hauan and Ann Helene Bolstad Skjelbred. Troms $\varnothing$ : Vett og Viten, 1995.

Otto, Bernd-Christian. Magie. Rezeptions- und diskursgeschichtliche Analysen von der Antike bis zur Neuzeit. Berlin: Walter de Gruyter, 2011.

Qvisling, Jon Lauritz. Mystiske fanomener $i$ menneskelivet. Kristiania: Aschehoug, 1909.

Raudvere, Catharina. "Trolldómr in Early Medieval Scandinavia." The Athlone History of Witchcraft and Magic in Europe: Witchcraft and Magic in the Middles Ages. Eds. Bengt Ankarloo and Stuart Clark. London: The Athlone Press, 2002.

Severi, Carlo. "Capturing Imagination: A Cognitive Approach to Cultural Complexity." Journal of the Royal Anthropological Institute 10.4 (2004): 815-838.

Skjelbred, Ann Helene Bolstad. “Troens grenser.” Tradisjon 25 (1995): 6370.

Slone, Jason. Theological Incorrectness. Why People Believe What They Shouldn't. Oxford: Oxford UP, 2004.

Solheim, Svale. Norsk satertradisjon. Oslo: Aschehoug, 1952.

Stockhammer, Robert. Die Wiederkehr der Magie und die Literatur 1880 1945. Berlin: Akademie-Verlag, 2000.

Stokker, Kathleen. Remedies and Rituals. Folk Medicine in Norway and the New Land. St. Paul: Minnesota Historical Society Press, 2007.

Sørensen, Jesper. "Charisma, Tradition, and Ritual: A Cognitive Approach to Magical Agency." Mind and Religion. Psychological and Cognitive Foundations of Religiosity. Eds. Harvey Whitehouse and Robert N. McCauley. Walnut Creek: Altamira, 2005.

Whitehouse, Harvey. Modes of Religiosity. A Cognitive Theory of Religious Transmission. Walnut Creek: Altamira, 2004.

Whitehouse, Harvey, and Luther H. Martin, eds. Theorizing Religions Past. Archeology, History, and Cognition. Walnut Creek: Altamira, 2004. 
Bereitgestellt von | Universitaetsbibliothek Basel

Angemeldet

Heruntergeladen am | 18.09.18 14:07 